RESEARCH ARTICLE

\title{
PRE-RELEASE TREATMENT IN CLASS II A CORRECTIONAL INSTITUTION OF PEKALONGAN
}

\author{
Ichwanul Fauzi Muslim ${ }^{l}$ \\ ${ }^{1}$ Postgraduate Program, Master of Laws, Universitas Negeri Semarang, Indonesia \\ $\triangle$ fauzimuslim28@gmail.com
}

HOW TO CITE

Muslim, I.F. (2020). Pre-Release Treatment in Class II A Correctional Institution of Pekalongan. Journal of Law and Legal Reform, 1(1), 93-106. DOI: https://doi.org/10.15294/jllr.vlil.35419

\begin{abstract}
Implementing pre-release treatment for a convict is one of the tasks of a correctional institution as a Technical Implementation Unit in the field of construction. Thus, a correctional institution, in implementing correctional guidance, must consider human right protections aspects for them to be balanced with the public interest. Convict constructions in a correctional institution is an effort conducted to enforce the law. The research examines how the pre-release treatment is a determined in Indonesia positive law and what obstacles are faced in the pre-release treatment process in Class II A Correctional Institution of Pekalongan. The study aims at finding out the provisions of the pre-release treatment in Indonesian positive law, the provision of pre-release treatment is one form of society construction processes that is conducted based on correctional system which aims to prepare the convicts to be able to integrate with the society. Therefore, they are able to play a role as a society member who owns freedom and responsibility before they are actually released.
\end{abstract}

Keywords: Pre-Release; Correctional Institution; Implementation 


\section{TABLE OF CONTENTS}

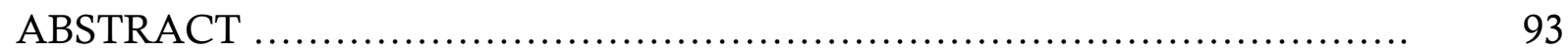

TABLE OF CONTENTS …................................................... 94

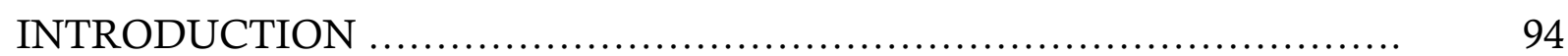

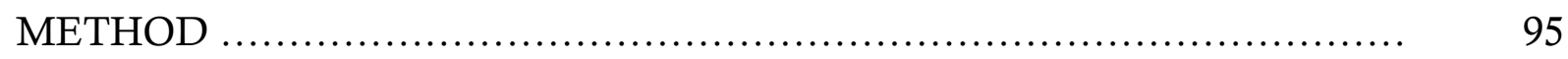

PRE-RELEASE AND CORRECTIONAL TREATMENT ..................... 95

I. OBSERVATION OF PRE-RELEASE AND CORRECTIONAL

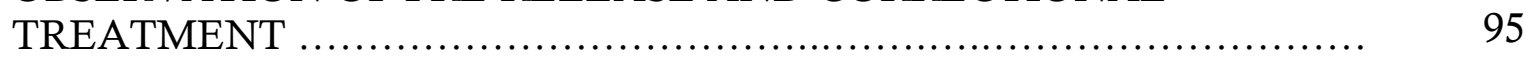

A. Definition Observation of Pre-Release .................................... 95

B. Giving Observation of Pre-Release ....................................... 96

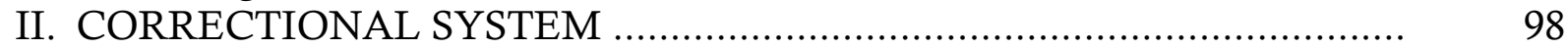

A. Definition of Correctional System ......................................... 98

B. Community Coaching Pattern ....................................... 99

PROVISIONS ON THE GRANTING OF LEAVE TOWARDS FREEDOM

IN INDONESIAN POSITIVE LAW ....................................... 100

I. THE BASIS OF GRANTING RELEASE IN INDONESIAN CRIMINAL JUSTICE SYSTEM ..................................................... 100

A. Idiil Basis .................................................................... 100

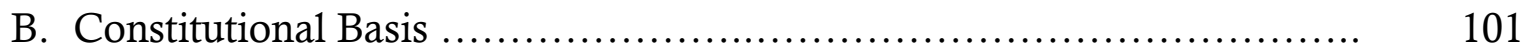

C. Operational Basis ................................................... 101

OBSTACLES AND HOW TO OVERCOME OBSTACLES IN THE

PROCESS OF LEAVING BEFORE BEING RELEASED IN CLASS II A

CORRECTIONAL INSTITUTION OF PEKALONGAN ....................... 101

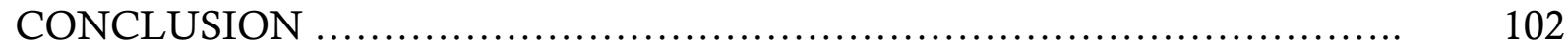

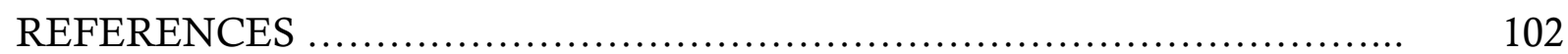

\section{INTRODUCTION}

Basically, crime, murder, theft, robbery, rape, etc. are various court actions which make the perpetrators languishing and receiving education under the title of Prisoner at the end of their graduation (release), or can make a degree Which is more level than recidivist if you sing it again and repeatedly (in and out) become residents of the place. It is very alarming indeed, if lately we hear as in our beloved country at this time the Terrorists that we hear or we watch through shows television or other media that is very disturbing to the public (Rahman, 1992).

Crimes occur in every space, place and time, crime is a phenomenon of human life. The only business that can be done is doing business that can prevent and reduce crime in the community (Puljević, Coomber, de Andrade, \& Kinner, 2019). Crimes are closely related to punishment, because those who have committed crimes should be brought to trial and sentenced to criminal penalties. The convicts then live behind prison walls that are completely foreign to him they mix and mingle with criminals 
from different forms of human behavior and different habits, as well as language, social stratification and diverse origins (Kansil \& Cristine, 2003).

Institutional formation of prisoners in its history in Indonesia is known since the enactment of the Prison Regulation 1971: 708, and this pattern was applied until 1963 (Euczyński, Pfingsthorn, \& Birk, 2017). Changes in views in treating prisoners in Indonesia are based on an evaluation of humanity which is a manifestation of the Pancasila as the basis for the nation's life outlook (Brinkley-Rubinstein et al., 2019). It also recognizes human rights, and after launching one of the most fundamental coaching philosophies by Saharjo that prisoners are not convicted people, but lost people who have the time and opportunity to repent. The repentance basically cannot be achieved with torture but with guidance and coaching (Irawan, 1995).

Given this point, there is a link that must be clearly considered by the supervisors and the government, how the coach is able to produce the prisoners so that they can still get recognition from the community after leaving prison (Al-Jumaili et al., 2018). One of the coaching in prison is to provide leave before release to prisoners who have fulfilled the requirements (Bucerius \& Haggerty, 2019). This is in accordance with article 15 paragraph 1 of the Criminal Law Book and the Law of the Republic of Indonesia No.12 of 1995 concerning correctional reads : "If the convict undergoes $2 / 3$ (two thirds) of the length of imprisonment imposed on him, at least it must be 9 months then he may be subject to Conditional Release or Pre-term Leave according to Law No.12 of 1995 if the convict must undergo several criminal consecutive crimes are considered as one criminal" (Balthazar, Vanacker, \& Lambin, 2012).

\section{METHOD}

This research is an Empirical Normative research that is by understanding Law Number 12 of 1995 Concerning Correctional Facilities and analyzing the implementation of leave before release in Class II Correctional Institution Pekalongan. The subjects of this research were Class II Correctional Institution Pekalongan and KA. Lapas Klas II A Pekalongan, while the object of this research is the implementation of leave before free in Lapas Klas II A Pekalongan. The method used by the author in compiling this journal is the Sociological Juridical Approach: Sociological Juridical Approach is legal research that uses the perspective of implementing the applicable laws and regulations. 


\section{PRE-RELEASE AND CORRECTIONAL TREATMENT}

\section{OBSERVATION OF PRE-RELEASE AND CORRECTIONAL TREATMENT}

\section{A. Definition Observation of Pre-Release}

The Criminal Code does not provide a clear resolution. Stages in the penal system, conditional release can be explained as the final phase (stage) in the prison process of prison which is a prison defense. Provisions on parole here are mandatory, but only apply outside (Chance, Hermosilla, Coops, Wulder, \& White, 2016). Conditional exemption related to the basic form will discuss more about the policy in negotiations related to the government. The implementation of defense to be released, part of the future that can be obtained by the convict the criminal is outside the prison wall (Cherniack et al., 2016). The release of the remaining part of the prison is called parole or Voorwardelijke invrijheidstelling (VI). Execution of exemptions related to several countries at this time are not executed. ) which throughout the criminal period was not executed (Sakidjo, 1998).

Elucidation of Law Number 12 of 1995 Article 6 paragraph (1) that the fostering of fostered citizens is carried out intramurally, that is, fostering is carried out in a penitentiary, while extramural fostering carried out in a penitentiary is called assimilation, namely the process of fostering of fostered citizens who have fulfilled certain conditions by blending them into people's lives (Cleary \& Brubaker, 2019).

Extramural guidance is also carried out by the correctional center called integration which is the process of guiding prisoners who have met certain requirements for life and being back in the community with the guidance and supervision of the correctional center (Davidson \& Young, 2019). And one of the implementation of such integration is by giving him leave before being released to prisoners or fostered citizens who have fulfilled certain conditions (Hamzah, 1983).

Article 15 of the Criminal Code does not mention the words of leave before being released, but a conditional release. In Law Number 12 Year 1995 article 6 paragraph (3) letter $b$, parole is equated with the meaning of leave before being free, there is only a slight difference. Article 15 paragraph (1) of the Criminal Code states that "If the convict has already made up two-thirds of the length of imprisonment imposed on him, then he may be subject to conditional release (Foge, Baldini, Hellwinkel, Hogan, \& Dayton, 2019). If the convict must undergo several crimes in a row, the criminal is considered as one criminal ". Law Number 12 Year 1995 article 6 paragraph (3) letter $b$ states that the guidance by the Penitentiary is conducted on "Prisoners, Criminal Children, and State Children who get parole or leave before release" (Hamzah, 1983).

Provision of observation pre-release is one of the inmates' training that is carried out based on a penal system that aims to prepare prisoners to be able to 
integrate healthily with the community so that they can play their role again as free and responsible community members (Gonzalez-Escamilla, Lange, Teipel, Buchert, \& Grothe, 2017). Inmates during their loss of freedom of movement must still be introduced to the community and should not be exiled. This problem can indeed lead to misunderstanding or can be considered a difficult problem to understand (Horton et al., 2017).

\section{B. Giving Observation of Pre-Release}

Observation of Pre-Release is part of a form of guidance in the penal system, one of the purposes of free leave leave to correct prison inmates. The correctional system is regulated in Law of the Republic of Indonesia Number 12 of 1995 Concerning Corrections, in Article 1 paragraph (2) stated that Correctional system is a structure regarding the direction and boundaries as well as ways of fostering prisoners based on Pancasila which are implemented in an integrated manner between Pancasila coaches, who are fostered, and the community to improve the quality of prison-assisted citizens so that they are aware of mistakes, improve themselves and do not repeat criminal acts so that they can actively play a role in development and can live naturally as good and responsible citizens (Muladi, 1985; Hurley, Claeson, Inzana, Gandhi, \& Child, 2019).

The legal basis for granting leave rights right before release is regulated in Republic of Indonesia Government Regulation Number 99 of 2012 concerning the Requirements and Procedure for the Implementation of Prisoners' Rights and the Minister of Law and Human Rights Regulation of the Republic of Indonesia Number 21 of 2016 concerning Terms and Procedures for Granting Remissions, Assimilation, Leave for Family Visit, Parole, Leave for Pre-release and Leave (Ibrahim et al., 2018).

Concerning the Terms and Procedure for the Implementation of the Rights of Penitentiaries, states:

a. Has served at least 2/3 (two thirds) of the criminal period, with the provision that $2 / 3$ (two thirds) of the criminal period is not less than 9 (nine) months.

b. Good behavior during serving a criminal period of at least the last 9 (nine) months calculated before the $2 / 3$ (two-thirds) of the criminal period.

c. The length of time before free leave is equal to the last remission, not later than 6 (six) months(Inness et al., 2015).

The procedure for granting Free Left Leave is as follows:

a. The correctional observer team after hearing the opinions of the members of the correctional observer team and studying the report on the development of coaching from the correctional guardians, proposed giving granting a free leave to the head of the Correctional Institution.

b. If the Head of Penitentiary agrees to the proposal of the correctional observer team, then forward the proposal to the head of the regional office of the Ministry of Law and Human Rights.

c. The head of the regional office on behalf of the minister may refuse or approve the granting of leave before being released after considering the results of the prison observation team session. 
d. If the head of the regional office of the Ministry of Law and Human Rights refuses to propose leave before being released, then within 14 (fourteen) days from the receipt of the proposal inform the rejection and its reasons to the head of the Correctional Institution.

e. If the head of the regional office of the legal and human rights department approves the proposed leave before release, within 14 (four days) days from the receipt of the proposal, it is forwarded to the director general of correctional services.

f. If the director general of correctional services agrees to the proposal to provide leave before release, the director general of correctional issues a decision on leave before release (Jin, Sun, Jiang, Wang, \& Wen, 2018).

\section{CORRECTIONAL SYSTEM}

\section{A. Definition Correctional System}

Understand the functions of Penitentiaries since then the correctional system was used as a method and correctional as a process. Penitentiary system as a method of fostering prisoners, is clearly happening changes in the function of a penal institution, which used to be a place of revenge as a place of formation (Lam et al., 2019).

The penitentiary system is a set of criminal law enforcement units, therefore its implementation cannot be separated from the development of a general conception of punishment. Prisoners are not as objects but also as subjects that are no different from other human beings who at any time can make mistakes or mistakes that can be subject to crime, so they do not have to be eradicated, and what must be eradicated are factors that can cause prisoners to do things that can be contrary to law, decency, religion or other social obligations that can be subject to criminal ( $\mathrm{Li}, \mathrm{Li}$, Liu, Xiong, \& Fang, 2018). Criminalization is an attempt to sensitize convicts or criminal children to regret their actions. Children who are guilty of coaching are placed in child prisons. Placement of children who are guilty in a child penitentiary are separated according to their respective status, namely criminal children, state children, and civil children. The difference in the status of the child is the basis for the distinction made in their formation (Luan, Ji, Chen, \& Cai, 2018).

The formation of institutional convicts in its history in Indonesia, is known since the enactment of Stbl Prison Regulation 1917 No. 708. This pattern has been renewed since the penal system is known with the characteristics of the main principles which all lead to the philosophy of prisoners rather than prisoners. Penitentiary system there is a penitentiary process which is defined as a process from the time a prisoner or student enters the correctional institution until it is released back into the midst of the community. Pursuant to SE.No.Kp.10.13 / 3/1 dated February 8, 1965, it has been established Corrections as a process in fostering inmates and carried out through four stages. The first stage is the maximum security stage to the limit of $1 / 3$ of the actual criminal period, the second stage is the medium security stage to the $1 / 2$ limit of the actual criminal period, the third stage is the minimum security stage to the limit of $2 / 3$ of the actual criminal period, the stage fourth is the 
integration stage and the completion of $2 / 3$ of the criminal period until the criminal period expires (Irawan, 1995).

Guidance of prisoners according to the penal system consists of coaching within institutions that include religious education, general education, skills courses, recreation, sports, arts, scouting, work training, assimilation, while coaching outside of institutions includes guidance during the convicted person gets conditional crime, research social. The penitentiary system explicitly states, prisoners have rights such as the right to correspondence, the right to be visited or visited, remission, leave, assimilation and conditional release, worship according to their religion, submit complaints, get services, health, get wages for work, obtaining parole and leave before parole (Martins et al., 2018).

\section{B. Community Coaching Pattern}

Based on the provisions of Article 6 of Law No. 12 of 1995, stated that: Guidance of correctional fostered citizens carried out in Penitentiary and guiding fostered prisoners are carried out by the Penitentiary while the fostering in Penitentiary is carried out on inmates and Penitentiary Students. Guidance of correctional fostered citizens in Penitentiary is carried out (Milosevic et al., 2018):

a. Intramurally (in Corrections Institutions)

b. Extremurally (outside Penitentiary)

Intramural guidance carried out in prisons is called assimilation, the process of fostering Penitentiary Citizens who have met certain requirements by blending them into people's lives (Polonik et al., 2019). Extensive guidance is also carried out by Bapas which is called integration, which is the process of guiding the Correctional Guidance Citizens who have met certain requirements to live and be back in the middle of the community with Bapas guidance and supervision (Pristiwati: 2009).

Extremural guidance is also carried out by the Penitentiary, called integration, which is the process of guiding prisoners who have met certain requirements for life and residing in the community with the guidance and supervision of the Penitentiary (Schilling et al., 2019). Guidance and guidance of correctional assisted residents carried out by correctional officers are correctional officers who implement the task of guiding, securing and guiding prisoners. Correctional officers are functional law enforcement officers who carry out duties in the field of guidance, security, and guidance of prisoners (Shi et al., 2019).

Article 1 paragraph (1) Government Regulation of the Republic of Indonesia Number 31 of 1999 concerning Guidance and Guidance of Correctional Prisoners explains: Coaching is an activity to improve the quality of devotion to God Almighty, intellectual, attitude and behavior, professional, physical and spiritual health (Rules Government of the Republic of Indonesia Number 31 of 1999 concerning Guidance and Guidance of Penitentiary Guidance Citizens Article 1) (Wang et al., 2019). The coaching aims so that the prisoner after finishing his criminal period will not repeat his actions (crime) and be able to live in a proper society and participate in development (Wang et al., 2019). 


\section{PROVISIONS ON THE GRANTING OF LEAVE TOWARDS FREEDOM IN INDONESIAN POSITIVE LAW}

\section{THE BASIS OF GRANTING RELEASE IN INDONESIAN CRIMINAL JUSTICE SYSTEM}

Correctional institutions are as one of the Government Institutions that carry out an activity in the field of fostering prisoners. To ensure legal certainty for the activities of inmates' guidance, a strong legal basis is needed. This is very necessary because the correctional institution in carrying out its functions must be in accordance with the provisions of the law that contain aspects of protecting one's human rights in balance with the public interest. Implementation of coaching relates to granting leave before release at the correctional facility always prioritizing the protection of human dignity. The implementation of guidance in correctional institutions is based on Pancasila by taking into account the provisions that set limits on the actions of restrictions or restrictions on human rights. Because every citizen has the right to equal treatment before the law by not making a difference (Kuswanto, 2002).

This equality of rights is based on the opinion that humans are the same before them, therefore the same degree, there must be no restraints that result in humiliation of human dignity, consequently everyone must respect others without distinguishing the nation, gender, origin, and others (Darmodiharjo, 1982). The legal basis for the treatment of prisoners' guidance processes in Indonesia, especially in Class II A penitentiary institutions, Pekalongan is:

1. Idiil Basis

2. Constitutional Basis

3. Operational Basis includes:

a. Law No. 1 of 1946 concerning the Criminal Law

b. Law No. 12 of 1995 concerning correctional facilities

c. Government Regulation No. 32 of 1999 concerning Terms and Procedures for the Implementation of the rights of fostered citizens

d. Decree of the Minister of Republic of Indonesia No.M.01-PK.04.10 of 1999 concerning assimilation, parole, and leave before release (Warren et al., 2019).

\section{A. Idiil Basis}

Pancasila is an Idiil Foundation which is the source of all sources of law and is also a source of legislation in force in Indonesia. Pancasila upholds human dignity and dignity, views humans as a round and whole unity, which has a soul and a body. Between soul and body must be harmonious and balanced. Penal Objectives improve and foster prisoners to be good human beings. Coaching towards them must be based on Pancasila. Various coaching efforts including giving leave before being released to 
prisoners who have met the requirements(Wasserman, Mor-Yossef, \& Greenberg, 2016).

\section{B. Constitutional Basis}

The 1945 Constitution is a Constitutional Basis which among other things in its preamble states that the State's goal is to protect all Indonesians and all of Indonesia's bloodbath, realize public welfare, educate the nation's life and participate in carrying out world order based on freedom, eternal peace and justice social (Winograd et al., 2019).

\section{Operational Basis}

1. Law No.l of 1946 concerning the Criminal Law Code.

2. Law No.12 of 1995 concerning Corrections.

3. Government Regulation No.32 of 1999 concerning Requirements and Procedures for the Implementation of the Rights of Fostered Persons.

4. Decree of the Minister of Justice of the Republic of Indonesia No. M.01-PK.04.10 of 1999 concerning Assimilation of Parole and Free Leave for Free (Xiang et al., 2019).

\section{OBSTACLES AND HOW TO OVERCOME OBSTACLES IN THE PROCESS OF LEAVING BEFORE BEING RELEASED IN CLASS II A CORRECTIONAL INSTITUTION OF PEKALONGAN}

Obstacles in the process of leaving before being released in Class II A Correctional Institution of Pekalongan starting from granting of leave before being released to prisoners is one part of the training carried out in Class II A Correctional Institution of Pekalongan as a manifestation that the prisoner concerned has shown change in behavior for the better. Granting leave before free must meet the predetermined requirements, namely substantive conditions and administrative requirements. Both of these conditions are always related and inseparable with the provision of leave before being free cannot always be carried out in accordance with the formula that has been determined. There are several obstacles that need attention so that the leave giver before being released to prisoners can run smoothly.

Efforts to overcome the barriers to leave before being free is overcome the above and at the same time the solver carried out by the Head of Prison is to establish cooperation between Government and private agencies including the Department of Religion in the context of fostering the convict's personality by fostering religious awareness, it is expected that prisoners will be able to strengthen their faith, with the understanding that prison fostering can realize the consequences of big deeds and wrong deeds and can carry out the Sharia according to their respective religions.

This guidance can be done through formal and non-formal education and recently Director General Pas has signed the Joint Decree with the Open University. 
This opportunity is not only intended for Penitentiary officials, but also for prisoners. It is hoped that through this collaboration intelligence can be improved by both officers and their assistants, while non-formal education is carried out according to the needs and abilities of Penitentiaries through skills training courses, public lecture activities and opening as wide opportunities as possible to obtain outside information, such as reading the newspaper, watching TV, listening to the radio, and so on. In order to catch up in the field of education, both formal and non-formal, learning is also done through the pursuit of the Package A program and the pursuit of business. In the field of fostering legal awareness the authors expect to work with the local District Court or Institution others or empowering Penitentiary officials who have a Bachelor of Law education background to provide legal counseling aimed at achieving a high level of legal awareness of prisoners so that they are aware of their rights and obligations in order to participate in upholding law and justice.

\section{CONCLUSION}

Guidance of prisoners needs to be improved relations with the community, because guiding prisoners is not solely charged to correctional officers but also becomes the duty and responsibility of the community. Therefore correctional officers must be able to encourage community involvement in coaching tasks.

\section{REFERENCES}

Al-Jumaili, S. K., Eaton, M. J., Holford, K. M., Pearson, M. R., Crivelli, D., \& Pullin, R. (2018). Characterisation of fatigue damage in composites using an Acoustic Emission Parameter Correction Technique. Composites Part B: Engineering, 151(March 2017), 237-244. https://doi.org/10.1016/j.compositesb.2018.06.020

Balthazar, V., Vanacker, V., \& Lambin, E. F. (2012). Evaluation and parameterization of ATCOR3 topographic correction method for forest cover mapping in mountain areas. International Journal of Applied Earth Observation and Geoinformation, 18(1), 436450. https://doi.org/10.1016/j.jag.2012.03.010

Brinkley-Rubinstein, L., Peterson, M., Clarke, J., Macmadu, A., Truong, A., Pognon, K., $\&$ Rich, J. D. (2019). The Benefits and Implementation Challenges of the First State-Wide Comprehensive Medication for Addictions Program in a unified Jail and Prison Setting. Drug and Alcohol Dependence, 205(June). https://doi.org/10.1016/j.drugalcdep.2019.06.016

Bucerius, S. M., \& Haggerty, K. D. (2019). Fentanyl behind bars: The implications of synthetic opiates for prisoners and correctional officers. International Journal of Drug Policy, 71, 133-138. https://doi.org/10.1016/j.drugpo.2019.05.018

Chance, C. M., Hermosilla, T., Coops, N. C., Wulder, M. A., \& White, J. C. (2016). Effect of topographic correction on forest change detection using spectral trend analysis of Landsat pixel-based composites. International Journal of Applied Earth 
Observation and Geoinformation, 44, 186-194. https://doi.org/10.1016/j.jag.2015.09.003 Cherniack, M., Dussetschleger, J., Dugan, A., Farr, D., Namazi, S., El Ghaziri, M., \& Henning, R. (2016). Participatory action research in corrections: The HITEC 2 program. Applied Ergonomics, 53(2015), 169-180. https://doi.org/10.1016/j.apergo.2015.09.011

Cleary, H. M. D., \& Brubaker, S. J. (2019). Therapeutic transformation of juvenile corrections in Virginia: A mixed method analysis of benefits and challenges. Children and Youth Services Review, 105(July), 104444. https://doi.org/10.1016/j.childyouth.2019.104444

Davidson, K. M., \& Young, J. T. N. (2019). Treatment engagement in a prison-based Therapeutic Community: A mixed-methods approach. Journal of Substance Abuse Treatment, 103(January), 33-42. https://doi.org/10.1016/j.jsat.2019.05.011

Foge, D. A., Baldini, T. H., Hellwinkel, J. E., Hogan, C. A., \& Dayton, M. R. (2019). The Role of Complete Posterior Cruciate Ligament Release in Flexion Gap Balancing for Total Knee Arthroplasty. Journal of Arthroplasty, 34(7), S361-S365. https://doi.org/10.1016/j.arth.2019.03.017

Gonzalez-Escamilla, G., Lange, C., Teipel, S., Buchert, R., \& Grothe, M. J. (2017). PETPVE12: an SPM toolbox for Partial Volume Effects correction in brain PET Application to amyloid imaging with AV45-PET. NeuroImage, 147, 669-677. https://doi.org/10.1016/j.neuroimage.2016.12.077

Hamzah, A. (1983). Suatu Tinjauan Ringkas Sistem Pemidanaan di Indonesia. Jakarta: Presindo Jakarta.

Horton, M., McDonald, R., Green, T. C., Nielsen, S., Strang, J., Degenhardt, L., \& Larney, S. (2017). A mapping review of take-home naloxone for people released from correctional settings. International Journal of Drug Policy, 46, 7-16. https://doi.org/10.1016/j.drugpo.2017.05.015

Hurley, R., Claeson, A., Inzana, J. A., Gandhi, A., \& Child, Z. (2019). 181. Sequential changes in lumbar lordosis and segmental stability following lateral interbody cage placement, Smith-Peterson Osteotomy, and anterior longitudinal ligament release. The Spine Journal, 19(9), S87-S88. https://doi.org/10.1016/j.spinee.2019.05.198 Ibrahim, A., Franz, B., Ahmad, Z., Healy, R., Knobelspiesse, K., Gao, B. C., ... Zhai, P. W. (2018). Atmospheric correction for hyperspectral ocean color retrieval with application to the Hyperspectral Imager for the Coastal Ocean (HICO). Remote Sensing of Environment, 204(April), 60-75. https://doi.org/10.1016/j.rse.2017.10.041

Inness, E. L., Mansfield, A., Biasin, L., Brunton, K., Bayley, M., \& McIlroy, W. E. (2015). Clinical implementation of a reactive balance control assessment in a subacute stroke patient population using a "lean-and-release" methodology. Gait and Posture, 41(2), 529-534. https://doi.org/10.1016/j.gaitpost.2014.12.005

Jin, X., Sun, I. Y., Jiang, S., Wang, Y., \& Wen, S. (2018). The relationships between job and organizational characteristics and role and job stress among Chinese community correctional workers. International Journal of Law, Crime and Justice, 52, 36-46. https://doi.org/10.1016/j.ijlcj.2017.09.002

Kansil, CST. (2003). Pengantar Hukum Indonesia. Jakarta: Balai Pustaka. 
Kuswanto. (2002). Pelaksanaan Pembebasan Bersyarat Di Lembaga Pemasyarakatan Kelas II.A Tegal, Tegal.

Lam, J. A., Lee, H. I. S., Truong, A. Q., Macmadu, A., Clarke, J. G., Rich, J., \& Brockmann, B. (2019). Brief video intervention to improve attitudes throughout medications for opioid use disorder in a correctional setting. Journal of Substance Abuse Treatment, 104(June), 28-33. https://doi.org/10.1016/j.jsat.2019.06.001

Li, X., Li, H., Liu, Y., Xiong, W., \& Fang, S. (2018). Joint release rate estimation and measurement-by-measurement model correction for atmospheric radionuclide emission in nuclear accidents: An application to wind tunnel experiments. Journal of Hazardous Materials, 345, 48-62. https://doi.org/10.1016/j.jhazmat.2017.09.051

Luan, H., Ji, F., Chen, Y., \& Cai, Z. (2018). statTarget: A streamlined tool for signal drift correction and interpretations of quantitative mass spectrometry-based omics Analytica Chimica Acta, 1036, 66-72. https://doi.org/10.1016/j.aca.2018.08.002

Euczyński, T., Pfingsthorn, M., \& Birk, A. (2017). The Pinax-model for accurate and efficient refraction correction of underwater cameras in flat-pane housings. Ocean Engineering, 133(October 2016), 9-22. https://doi.org/10.1016/j.oceaneng.2017.01.029

Martins, V. S., Soares, J. V., Novo, E. M. L. M., Barbosa, C. C. F., Pinto, C. T., Arcanjo, J. S., \& Kaleita, A. (2018). Continental-scale surface reflectance product from CBERS-4 MUX data: Assessment of atmospheric correction method using coincident Landsat observations. Remote Sensing of Environment, 218(July), 55-68. https://doi.org/10.1016/j.rse.2018.09.017

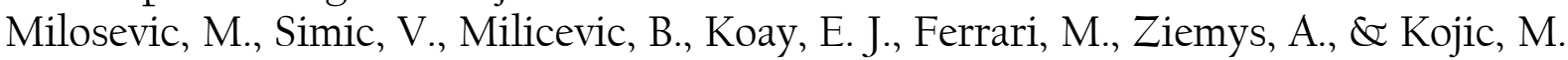
(2018). Correction function for accuracy improvement of the Composite Smeared Finite Element for diffusive transport in biological tissue systems. Computer Methods in Applied Mechanics and Engineering, 338, 97-116. https://doi.org/10.1016/j.cma.2018.04.012

Muladi. (1992). Lembaga Pidana Bersyarat. Bandung: Mandar Maju.

Petrus, I. P. (1995). Lembaga Pemasyarakatan dalam Perspektif Sistem Peradilan Pidana. Jakarta: Pustaka Sinar Harapan.

Polonik, P., Chan, W. S., Billesbach, D. P., Burba, G., Li, J., Nottrott, A., \& Biraud, S. C. (2019). Comparison of gas analyzers for eddy covariance: Effects of analyzer type and spectral corrections on fluxes. Agricultural and Forest Meteorology, 272273(February), 128-142. https://doi.org/10.1016/j.agrformet.2019.02.010

Pristiwati, R. (2009). Pola Pembinaan Narapidana Di Lembaga Pemasyarakatan Klas IIA Wanita Tanjung Gusta Medan. Thesis. Medan: Postgraduate Program Universitas Sumatera Utara.

Puljević, C., Coomber, R., de Andrade, D., \& Kinner, S. A. (2019). Barriers and facilitators of maintained smoking abstinence following release from smoke-free prisons: A qualitative enquiry. International Journal of Drug Policy, 68, 9-17. https://doi.org/10.1016/j.drugpo.2019.03.018

Rahman, A. (1992). Tindak Pidana dalam Syariat Islam. Jakarta: Rineka Cipta.

Sakidjo, A., \& Poernomo, B. (1990). Hukum Pidana Dasar Aturan Umum Hukum Pidana 
Kodifikasi, Jakarta: Ghalia Indonesia.

Schilling, K. G., Blaber, J., Huo, Y., Newton, A., Hansen, C., Nath, V., ... Landman, B. A. (2019). Synthesized b0 for diffusion distortion correction (Synb0-DisCo). Magnetic Resonance Imaging, (May), 0-1. https://doi.org/10.1016/j.mri.2019.05.008

Shi, J., Ordway, N. R., Sun, M. H., Albanese, S. A., Kurra, S., \& Lavelle, W. F. (2019). 25. Use of precontoured titanium alloy rods to induce thoracic kyphosis after sequential posterior release: a cadaveric spine study. The Spine Journal, 19(9), S12S13. https://doi.org/10.1016/j.spinee.2019.05.038

Wang, S. L., Fernandez, C., Zou, C. Y., Yu, C. M., Chen, L., \& Zhang, L. (2019). A comprehensive working state monitoring method for power battery packs considering state of balance and aging correction. Energy, 444-455. https://doi.org/10.1016/j.energy.2019.01.020

Warren, M. A., Simis, S. G. H., Martinez-Vicente, V., Poser, K., Bresciani, M., Alikas, K., ... Ansper, A. (2019). Assessment of atmospheric correction algorithms for the Sentinel-2A MultiSpectral Imager over coastal and inland waters. Remote Sensing of Environment, 225(March), 267-289. https://doi.org/10.1016/j.rse.2019.03.018

Wasserman, M., Mor-Yossef, Y., \& Greenberg, J. B. (2016). A positivity-preserving, implicit defect-correction multigrid method for turbulent combustion. Journal of Computational Physics, 316(April), 303-337. https://doi.org/10.1016/j.jcp.2016.04.005

Winograd, R. P., Wood, C. A., Stringfellow, E. J., Presnall, N., Duello, A., Horn, P., \& Rudder, T. (2019). Implementation and evaluation of Missouri's Medication First treatment approach for opioid use disorder in publicly-funded substance use treatment programs. Journal of Substance Abuse Treatment. https://doi.org/10.1016/j.jsat.2019.06.015

Xiang, G., Lippens, E., Hafeez, S., Duda, G. N., Geissler, S., \& Qazi, T. H. (2019). Oxidized alginate beads for tunable release of osteogenically potent mesenchymal stromal cells. Materials Science and Engineering C, 104(June), 109911. https://doi.org/10.1016/j.msec.2019.109911 


\author{
Quote
}

\title{
We have a racially based justice system that overpunishes, fails to rehabilitate, and doesn't make us safer.
}

Piper Kerman,

Orange Is the New Black 